\title{
Pertumbuhan dan hasil Kailan (Brassica oleracea var. Alboglabra) pada berbagai dosis pupuk kambing dan frekuensi pemupukan Nitrogen
}

Growth and yield of Kale (Brassica oleracea var. Alboglabra) on several doses of goat manure and Nitrogen fertilizing frequency

\author{
Sahla Laksmita Fathin*, Endang Dwi Purbajanti, dan Eny Fuskhah \\ Program Studi Agroekoteknologi, Departemen Pertanian, Fakultas Peternakan dan Pertanian \\ Universitas Diponegoro, Tembalang, Semarang, 50275 - Indonesia \\ *Correspondence authors: sahlalaksmita11@gmail.com
}

\section{ABSTRACT}

Goat manure is an organic fertilizer that provides nutrients and improves soil physical properties, but organic fertilizer has poor nitrogen content so it needs continued nitrogen fertilizing. Urea can fulfilled nitrogen nutrient for kale. Urea can easily los so that the right frequency is needed. This research aimed to identify the effect of several doses of goat manure and application of nitrogen fertilizer on different frequency on growth and yield of kale (Brassica oleracea var. Alboglabra). The research used factorials experiment $4 \times 3$ with Randomized Complete Block Design (RCBD) consisting of 3 replications. The first treatment was several doses of goat's feces fertilizer such as K0: 0 ton/ha, K1: 10 ton/ha, K2: 20 ton/ha, K3: 30 ton/ha. The second treatment was different nitrogen fertilizing frequency such as N1: one time (2 Week After Planting), N2: two times (2, 3 Week After Planting), N3: three times (2, 3, 4 Week After Planting). The results showed that dose of goat manure in 30 tons/ha produces the highest significantly response to production of kale. Nitrogen fertilization frequency three and two times both gives the best results on plant height, number of leaves, and canopy wet weight. There was no effect of both the dose of goat manure and the frequency of nitrogen fertilization on ANR levels. This research was concluded that the dose of goat manure 30 tons/ha and nitrogen fertilizing frequency twice, showed the most effective growth and yield of kale.

Keywords : kn qqale, goat's feces fertilizer, nitrogen fertilizing

\begin{abstract}
ABSTRAK
Pupuk kandang kambing merupakan pupuk organik yang befrungsi sebagai penyedia hara dan memperbaiki sifat fisik tanah, namun pupuk organik mengandung hara nitrogen yang sedikit sehingga perlu pemupukan nitrogen lanjutan. Pupuk urea dapat mencukupi kebutuhan unsur nitrogen kailan. Kekurangan pupuk urea yaitu bersifat mobil sehingga diperlukan frekuensi yang tepat. Penelitian ini bertujuan mengkaji pengaruh berbagai dosis pupuk kandang kambing dan frekuensi pemupukan nitrogen terhadap pertumbuhan dan hasil tanaman kaillan (Brassica oleracea var. Alboglabra). Penelitian ini menggunakan percobaan faktorial 4 x 3 dengan Rancangan Acak Kelompok (RAK) terdiri dari 3 kelompok ulangan. Faktor pertama yaitu dosis pupuk kandang kambing (K) yaitu: K0: 0 ton/ha, K1: 10 ton/ha, K2: 20 ton/ha, K3: 30 ton/ha. Faktor kedua yaitu frekuensi pemupukan nitrogen (N) yaitu: N1: satu kali (2 MST), N2: dua kali (2, 3 MST), N3: tiga kali (2, 3, 4 MST). Hasil penelitian menunujkkan perlakuan dosis pupuk kandang kambing 30 ton/ha memberikan hasil terbaik terhadap produksi tanaman kailan. Frekuensi pemupukan nitrogen tiga dan dua kali memberikan hasil terbaik terhadap tinggi tanaman, jumlah daun, dan bobot basah tajuk. Tidak ada pengaruh baik dosis pupuk kandang kambing dan frekuensi pemupukan nitrogen terhadap kadar ANR. Berdasarkan hasil penelitian disimpulkan bahwa dosis pupuk kandang kambing 30 ton/ha dan frekuensi pemupukan nitrogen sebanyak dua kali, menunjukkan pertumbuhan dan hasil tanaman kailan yang paling efektif.
\end{abstract} Kata kunci : kailan, pupuk kandang kambing, pemupukan nitrogen 


\section{PENDAHULUAN}

Tanaman kailan (Brassica oleracea var. Alboglabra) atau yang lebih dikenal dengan chinese broccoli merupakan salah satu jenis sayuran famili kubis-kubisan (Brassicaceae). Kalian memiliki nilai gizi yang tinggi dan bermanfaat bagi kesehatan. Kadar gizi yang terdapat pada sayur kailan yaitu sebagai sumber vitamin, seperti vitamin $\mathrm{A}, \mathrm{B}, \mathrm{C}$, serat, dan mineral, seperti $\mathrm{Ca}, \mathrm{P}, \mathrm{Fe}, \mathrm{Na}, \mathrm{F}, \mathrm{S}$, dan $\mathrm{Cl}$ (Sinaga et al. 2014). Kailan memiliki manfaat yaitu menghaluskan kulit, antioksidan untuk mencegah kanker, sumber zat besi, dan mencegah infeksi. Kailan cocok ditanam pada tanah lempung sampai lempung berpasir yang mengandung bahan organik, $\mathrm{pH}$ tanah optimum $6-6,8$, dengan ketinggian tempat $700-1.500$ $\mathrm{m}$ di atas permukaan laut (dpl). Suhu rata-rata harian yang dikehendakai tanaman kailan adalah $23-35^{\circ} \mathrm{C}$ (Wahyudi, 2010).

Pupuk merupakan komponen yang penting untuk pertumbuhan dan produktivitas tanaman. Pemupukan adalah usaha menambahkan unsur hara untuk tanaman, baik pada tajuk tanaman atau tanah sesuai kebutuhan tanaman, yang bertujuan melengkapi ketersediaan unsur hara. Pupuk dibedakan menjadi pupuk organik dan anorganik. Salah satu contoh pupuk organik yaitu pupuk kandang. Pupuk kandang kambing memiliki volume ruang pori yang tinggi sehingga dapat meningkatkan porositas tanah. Apabila porositas tanah baik, bahan organik yang terdapat dalam tanah akan tertahan dan dapat memperbaiki sifat fisik, kimia, dan biologi tanah untuk pertumbuhan tanaman (Rahayu et al. 2014). Pupuk kandang kambing mengandung unsur nitrogen yang baik untuk pertumbuhan vegetatif tanaman seperti tinggi tanaman, jumlah daun, dan luas daun. Kandungan unsur $\mathrm{N}$ pada pupuk kandang kambing sebesar $0,55 \%$, sedangkan kandungan unsur hara $\mathrm{P}$ dan $\mathrm{K}$ masing-masing adalah $0,31 \%$ dan $0,15 \%$ (Roidah, 2013). Tanaman yang diberi pupuk kandang kambing mengandung unsur $\mathrm{N}, \mathrm{P}, \mathrm{K}$ yang tercukupi, sehingga kemampuan tanaman untuk menghasilkan asimilat tinggi sebagai akibat optimalnya proses metabolisme tanaman, terutama fotosintesis (Suminarti, 2010).

Penyediaan hara pupuk organik terbatas dan tidak cukup dalam menyediakan unsur hara yang dibutuhkan tanaman sehingga kurang baik untuk pertumbuhan dan perkembangan tanaman (Trisnawati et al. 2018). Hara pada pupuk organik yang lambat tersedia maka diperlukan kombinasi dengan pupuk anorganik. Penggunaan pupuk anorganik dapat menjadi solusi dan alternatif dalam meningkatkan pertumbuhan tanaman kailan. Penggunaan pupuk anorganik diharapkan dapat mempermudah pengaplikasian di lahan dan dapat meningkatkan unsur hara yang dibutuhkan di dalam tanah. Pemberian pupuk anorganik mampu menyuplai kebutuhan unsur hara pada tanaman dalam keadaan tersedia sehingga dapat dimanfaatkan secara langsung oleh tanaman (Lestari dan Kuntyastuti, 2016). Apabila dosis pupuk anorganik sesuai dengan kebutuhan tanaman, maka kebutuhan tanaman akan unsur hara dapat terpenuhi (Hariodamar et al. 2018).

Pupuk urea memiliki kandungan hara nitrogen $46 \%$. Unsur nitrogen merupakan unsur yang sangat penting untuk pertumbuhan vegetatif tanaman, khususnya tanaman sayur seperti kailan untuk mendapatkan hasil produksi yang baik. Pupuk urea sudah memiliki unsur nitrogen yang langsung tersedia dan sesuai dengan kebutuhan tanaman kailan yang berumur pendek. Nitrogen dalam jumlah yang cukup berperan untuk mempercepat pertumbuhan vegetatif yaitu bagian batang dan daun tanaman (Haryadi et al. 2015). Pupuk urea memiliki kelebihan yaitu cepat tersedia dan terserap oleh tanaman. Kekurangan yang dimiliki pupuk urea juga memiliki yaitu cepat hilang yang disebabkan oleh penguapan dan pencucian karena pupuk urea bersifat mobil (Putra et al. 2015). Aplikasi pupuk anorganik pada tanah dapat meningkatkan pertumbuhan dan hasil tanaman dengan dikombinasikan bahan organik untuk meningkatkan kation pada daerah perakaran dan menekan tercucinya hara, sehingga daya serap tanaman optimal (Yuliarta et al. 2014). 


\section{BAHAN DAN METODE}

Penelitian ini akan dilaksanakan pada Mei 2019 hingga Juni 2019 di Desa Sukoharjo, Kecamatan Pabelan, Kabupaten Semarang serta dilanjutkan dengan analisis di laboratorium Ekologi dan Produksi Tanaman dan Fisiologi dan Pemuliaan Tanaman, Fakultas Peternakan dan Pertanian, Universitas Diponegoro, Semarang. Penelitian dilakukan di lahan dengan jenis tanah latosol berukuran $200 \mathrm{~m}^{2}$ dan terdapat 36 petak. Kecamatan Pabelan terletak di antara $110^{\circ} 29^{\prime} 36^{\prime \prime}-110^{\circ} 35^{\prime} 14$ ' Bujur Timur dan 7¹5'24" - 7'20'45" Lintang Selatan dengan ketinggian daerah pada 627 meter diatas permukaan laut (m dpl).

Bahan yang digunakan dalam penelitian adalah benih kailan, pupuk kandang kambing, pestisida, dan pupuk urea. Alat yang digunakan adalah meteran, tray, sprayer, selang, penggaris, spektrofotometer, oven, dan timbangan. Penelitian menggunakan Rancangan Acak Kelompok pola Faktorial 4x3 dengan 3 ulangan. Faktor pertama adalah dosis pupuk kandang kambing $(\mathrm{K})$ yaitu: K0: 0 ton/ha, K1: 10 ton/ha, K2: 20 ton/ha, K3: 30 ton/ha. Faktor kedua adalah frekuensi pemupukan nitrogen $(\mathrm{N})$ yaitu: N1: satu kali (2 MST), N2: dua kali (2, 3 MST), N3: tiga kali (2, 3, 4 MST). Kombinasi perlakuan sebanyak 12 dengan 3 kelompok ulangan, sehingga terdapat 36 unit percobaan yang setiap unit percobaan.

Penelitian dilakukan melalui 2 tahap yaitu tahap persiapan dan pelaksanaan. Persiapan penelitian meliputi pembelian bahan dan peralatan di toko pertanian. Tahap pelaksanaan meliputi pengolahan tanah, lahan yang digunakan dibersihkan dan dicangkul hingga tanah menjadi gembur dijadikan bedeng. Bedeng lahan menggunakan jarak antara tanaman di dalam satu bedeng adalah $30 \mathrm{~cm} \mathrm{x}$ $30 \mathrm{~cm}$, dengan jarak tanam antar bedengan 50 $\mathrm{cm}$. Luas bedengan $50 \times 210 \mathrm{~cm}$, terdapat 6 sampel tanaman yang terletak ditengah bedeng. Pemberian perlakuan diberikan saat pengolahan tanah dengan cara dicampur secara merata sesuai dosis pupuk kandang kambing. Persemaian dilakukan dengan memilih mutu benih yang memiliki kriteria yang unggul.
Media tanam yang digunakan berupa pupuk kandang kambing dan tanah dengan perbandingan 1:1 yang kemudian dicampur dan dimasukkan ke dalam tray. Penanaman dilakukan setelah bibit berumur 2 MSS atau sudah memiliki daun sejumlah 3-4 helai daun. Bibit hasil semai dipindahkan ke lahan bedeng dan ditanam pada lubang tanam yang sudah disiapkan dengan jarak tanam $30 \times 30 \mathrm{~cm}$. Setiap lubang, ditanam satu bibit dan pemindahan dilakukan pada sore hari untuk menghindari kelayuan pada tanaman yang sudah dipindahkan. Pemberian perlakuan pemupukan $\mathrm{N}$ dilakukan setelah tanaman berumur 14 hari setelah tanam di lahan dengan ditugal pada masing masing tanaman. Pemeliharaan dilakukan antara lain penyiraman, penyulaman, penyiangan dan pengendalian hama dan penyakit. Pemanenan dilakukan pada saat tanaman berumur 6 MST dengan cara mencabut seluruh tanaman. Parameter yang diamati dalam penelitian ini adalah tinggi tanaman, jumlah daun, luas daun, bobot segar tajuk dan akar, bobot kering tajuk dan akar, kadar klorofil total, kadar ANR (Aktivitas Nitrat Reduktase), indeks panen.

Data yang diperoleh kemudian diolah secara statistik dengan analisis ragam, apabila diperoleh pengaruh perlakuan nyata maka dilakukan uji lanjut untuk mengetahui pembandingan nilai rata rata antar perlakuan dengan uji DMRT (Duncan's Multiple Range Test) pada taraf $5 \%$.

\section{HASIL DAN PEMBAHASAN}

\section{Tinggi Tanaman}

Hasil analisis ragam menunjukkan bahwa dosis pupuk kandang kambing dan frekuensi pemupukan nitrogen masing-masing berpengaruh nyata terhadap tinggi tanaman. Tidak terdapat pengaruh interaksi antara dosis pupuk kandang kambing dan frekuensi pemupukan nitrogen terhadap tinggi tanaman. Rerata tinggi tanaman kailan (Brassica oleracea var. Alboglabra) pada berbagai dosis pupuk kandang kambing dan frekuensi pemupukan nitrogen dapat dilihat pada Tabel 1 . 
Tabel 1. Rerata Tinggi Tanaman Kailan (Brassica oleracea var. Alboglabra) pada Dosis Pupuk Kandang Kambing dan Frekuensi Pemupukan Nitrogen

\begin{tabular}{ccccc}
\hline \multirow{2}{*}{$\begin{array}{c}\text { Pupuk kandang } \\
\text { kambing (ton/ha) }\end{array}$} & \multicolumn{3}{c}{ Frekuensi pemupukan nitrogen (kali) } & \multirow{2}{*}{ Rerata } \\
\cline { 2 - 3 } 0 & Satu (2 MST) & Dua (2, 3, MST) & Tiga $(2,3,4$ MST) & \\
\hline 0 & 8,62 & $----(\mathrm{cm})----$ & \\
10 & 9,26 & 10,18 & 9,76 & $9,52^{\mathrm{b}}$ \\
20 & 10,48 & 11,51 & 11,04 & $10,60^{\mathrm{b}}$ \\
30 & 13,00 & 12,19 & 15,79 & $12,82^{\mathrm{a}}$ \\
Rerata & $10,34^{\mathrm{b}}$ & 14,62 & 15,84 & $14,49^{\mathrm{a}}$ \\
\hline
\end{tabular}

Keterangan: Superskrip yang berbeda pada kolom atau baris yang sama menunjukkan perbedaan nyata pada uji DMRT taraf $5 \%$.

Berdasarkan Tabel 1. diketahui bahwa rerata tinggi tanaman kailan dipengaruhi oleh dosis pupuk kandang kambing dan frekuensi pemupukan nitrogen secara sendiri. Perlakuan dosis pupuk kandang kambing 20 ton/ha dan 30 ton/ha meningkatkan tinggi tanaman secara signifikan dibandingakan dengan perlakuan tanpa pupuk dan dosis pupuk 10 ton/ha. Dosis pupuk kandang kambing 20 ton/ha menghasilkan tinggi tanaman sebesar 12,82 $\mathrm{cm}$, dan dosis 30 ton/ha menghasilkan tinggi tanaman sebesar 14,49 cm. Pupuk kandang kambing dapat menggemburkan lapisan tanah karena terksturnya remah sehingga dapat meningkatkan porositas tanah yang baik untuk kesuburan tanah. Hal ini sesuai dengan pendapat Rahayu et al. (2014) yang menyatakan bahwa pupuk kandang kambing bertekstur remah serta memiliki butiran-butiran kasar menjadikan media memiliki volume ruang pori tinggi sehingga meningkatkan porositas tanah. Apabila porositas tanah baik, bahan organik yang terdapat dalam tanah akan tertahan. Bahan organik yang tertahan dapat memperbaiki sifat fisik, kimia, dan biologi tanah yang baik untuk pertumbuhan tanaman. Pupuk kandang kambing selain memiliki sifat fisik yang baik, juga mengandung unsur hara penting untuk pertumbuhan tanaman kailan. Menurut Azizah et al. (2016) pupuk kandang kambing mengandung unsur $\mathrm{N}$ yang dapat mencukupi kebutuhan unsur $\mathrm{N}$ tanaman selama pertumbuhan pada fase vegetatif, sehingga meningkatkan tinggi tanaman.
Perlakuan frekuensi pemupukan nitrogen dua dan tiga kali meningkatkan tinggi tanaman secara signifikan dibandingkan dengan pemupukan nitrogen sekaligus. Pemupukan nitrogen dengan frekuensi sebanyak dua kali menghasilkan tinggi tanaman sebesar 12,11 $\mathrm{cm}$, dan frekuensi pemupukan nitrogen sebanyak tiga kali menghasilkan tinggi tanaman sebesar $13,11 \mathrm{~cm}$. Pemberian pupuk nitrogen dengan dosis dan waktu aplikasi aplikasi yang tepat menyebabkan tanaman menyerap unsur hara $\mathrm{N}$ secara optimal. Serapan hara $\mathrm{N}$ yang optimal berpengaruh pada pertumbuhan tinggi tanaman kailan. Hal ini sesuai dengan pendapat Pramitasari et al. (2016) yang menyatakan bahwa apabila tanaman menyerap unsur hara dengan kandungan yang tinggi hingga batas optimum dapat berpengaruh terhadap tinggi tanaman. Kandungan unsur hara $\mathrm{N}$ yang tinggi dapat meningkatkan pertumbuhan vegetatif khususnya tinggi tanaman. Erawan et al. (2013) menyatakan bahwa unsur $\mathrm{N}$ berfungsi dalam pertumbuhan vegetatif tanaman, nitrogen merupakan unsur hara esensial untuk pembelahan dan perpanjangan sel, sehingga $\mathrm{N}$ merupakan penyusun protoplasma yang banyak terdapat dalam jaringan seperti titik tumbuh

\section{Jumlah Daun}

Hasil analisis ragam menunjukkan bahwa dosis pupuk kandang kambing dan frekuensi pemupukan nitrogen masing-masing berpengaruh nyata terhadap jumlah daun. Tidak terdapat pengaruh interaksi antara dosis 
Tabel 2. Rerata Jumlah Daun Kailan (Brassica oleracea var. Alboglabra) pada Dosis Pupuk Kandang Kambing dan Frekuensi Pemupukan Nitrogen.

\begin{tabular}{ccccc}
\hline \hline \multirow{2}{*}{$\begin{array}{c}\text { Pupuk kandang } \\
\text { kambing (ton/ha) }\end{array}$} & \multicolumn{3}{c}{ Frekuensi pemupukan nitrogen (kali) } & \multirow{2}{*}{ Rerata } \\
\cline { 2 - 3 } & Satu (2 MST) & Dua (2, 3, MST) & Tiga $(2,3,4$ MST) & \\
\hline 0 & 7,95 & $-----($ helai)----- & $8,54^{\mathrm{b}}$ \\
10 & 8,28 & 8,72 & 8,94 & $9,22^{\mathrm{b}}$ \\
20 & 9,33 & 10,01 & 9,39 & $10,13^{\mathrm{a}}$ \\
30 & 10,66 & 10,00 & 11,05 & $11,11^{\mathrm{a}}$ \\
Rerata & $9,05^{\mathrm{b}}$ & 11,05 & 11,61 & \\
\hline
\end{tabular}

Keterangan: Superskrip yang berbeda pada kolom atau baris yang sama menunjukkan perbedaan nyata pada uji DMRT $\operatorname{taraf} 5 \%$.

pupuk kandang kambing dan frekuensi pemupukan nitrogen terhadap jumlah daun. Rerata jumlah daun tanaman kailan (Brassica oleracea var. Alboglabra) pada berbagai dosis pupuk kandang kambing dan frekuensi pemupukan nitrogen dapat dilihat pada Tabel 2

Berdasarkan Tabel 2. diketahui bahwa rerata jumlah daun tanaman kailan dipengaruhi oleh dosis pupuk kandang kambing dan frekuensi pemupukan nitrogen secara sendiri. Perlakuan dosis pupuk kandang kambing 20 ton/ha dan 30 ton/ha meningkatkan tinggi tanaman secara signifikan dibandingakan dengan perlakuan tanpa pupuk dan dosis pupuk 10 ton/ha. Dosis pupuk kandang kambing 20 ton/ha menghasilkan jumlah daun sebanyak 10,13 helai, dan dosis 30 ton/ha menghasilkan jumlah daun sebanyak 11,11 helai. Unsur hara yang terdapat pada pupuk kandang kambing khususnya $\mathrm{N}$ dapat meningkatkan pertumbuhan vegetatif tanaman kailan khususnya jumlah daun. Hal ini sesuai dengan pendapat Azizah et al. (2016) yang menyatakan bahwa pupuk kotoran kambing mengandung unsur hara $\mathrm{N}$ yang dapat meningkatkan pertumbuhan daun sehingga daun akan menjadi lebih banyak jumlahnya.

Perlakuan frekuensi pemupukan nitogen dua dan tiga kali meningkatkan jumlah daun secara signifikan dibandingkan dengan pemupukan nitrogen sekaligus. Pemupukan nitrogen dengan frekuensi sebanyak dua kali meningkatkan jumlah daun menjadi sebanyak 9,95 helai, dan frekuensi pemupukan nitrogen sebanyak tiga kali meningkatkan jumlah daun menjadi sebanyak 10,25 helai. Unsur hara N pada pupuk urea sudah tersedia sehingga dapat langsung diserap oleh tanaman. Pemupukan urea dengan dosis dan waktu aplikasi yang tepat dapat menyuplai kebutuhan $\mathrm{N}$ tanaman sesuai jumlah yang dibutuhkan untuk merangsang pembentukan daun. Hal ini sesuai dengan pernyataan Rajak et al. (2016) yang menyatakan bahwa pupuk urea mampu menyuplai unsur $\mathrm{N}$ yang dibutuhkan untuk proses pertumbuhan dan perkembangan tanaman khususnya dalam pertambahan jumlah daun.

\section{Luas Daun}

Hasil analisis ragam menunjukkan bahwa dosis pupuk kandang kambing berpengaruh nyata terhadap luas daun, sedangkan frekuensi pemupukan nitrogen tidak berpengaruh nyata. Tidak terdapat pengaruh interaksi antara dosis pupuk kandang kambing dan frekuensi pemupukan nitrogen terhadap luas daun. Rerata luas daun tanaman kailan (Brassica oleracea var. Alboglabra) pada berbagai dosis pupuk kandang kambing dan frekuensi pemupukan nitrogen dapat dilihat pada Tabel 3.

Berdasarkan Tabel 3. diketahui bahwa rerata luas daun tanaman kailan dipengaruhi oleh dosis pupuk kandang kambing, namun tidak dipengaruhi oleh frekuensi pemupukan nitrogen. Perlakuan dosis pupuk kandang kambing 20 ton/ha dan 30 ton/ha meningkatkan luas daun secara signifikan dibandingakan dengan perlakuan tanpa pupuk dan dosis pupuk 10 ton/ha yang belum mampu meninngkatkan 
Tabel 3. Rerata Luas Daun Kailan (Brassica oleracea var. Alboglabra) pada Dosis Pupuk Kandang Kambing dan Frekuensi Pemupukan Nitrogen.

\begin{tabular}{ccccc}
\hline \multirow{2}{*}{$\begin{array}{c}\text { Pupuk kandang } \\
\text { kambing (ton/ha) }\end{array}$} & \multicolumn{3}{c}{ Frekuensi pemupukan nitrogen (kali) } & \multirow{2}{*}{ Rerata } \\
\cline { 2 - 3 } 0 & Satu (2 MST) & Dua $(2,3, \mathrm{MST})$ & Tiga $(2,3,4 \mathrm{MST})$ & \\
\hline 0 & 115,06 & $----\left(\mathrm{cm}^{2}\right)----$ & \\
10 & 98,66 & 116,31 & 97,42 & $109,60^{\mathrm{c}}$ \\
20 & 139,20 & 151,06 & 117,97 & $122,56^{\mathrm{bc}}$ \\
30 & 166,05 & 145,76 & 161,71 & $148,49^{\mathrm{a}}$ \\
Rerata & 129,74 & 177,12 & 187,26 & $176,81^{\mathrm{a}}$ \\
\hline
\end{tabular}

Keterangan: Superskrip yang berbeda pada kolom yang sama menunjukkan perbedaan nyata pada uji DMRT taraf 5\%.

luas daun tanaman kailan. Perlakuan dosis pupuk kandang kambing 20 ton/ha menghasilkan luas daun sebesar $148,48 \mathrm{~cm}^{2}$, dan dosis pupuk 30 ton/ha menghasilkan luas daun sebesar $176,81 \mathrm{~cm}^{2}$. Semakin tinggi dosis pupuk kandang kambing maka semakin tinggi luas daun yang dihasilkan. Pupuk kandang kambing mengandung unsur makro yang baik untuk pertumbuhan tanaman antara lain nitrogen, kalium dan fosfor. Hal ini sesuai dengan pendapat Suparhun et al. (2015) yang menyatakan bahwa unsur $\mathrm{N}$ yang terkandung pada pupuk kandang kambing mendorong pertumbuhan organ-organ yang berkaitan dengan fotosintesis yaitu daun. Unsur $\mathrm{K}$ berperan sebagai aktivator berbagai enzim dalam reaksi-reaksi fotosintesis dan respirasi serta untuk enzim yang terlibat dalam sistesis protein dan pati. Unsur P merupakan unsur penting penyusun Adenosin Triphosphate (ATP) yang secara langsung berperan dalam proses penyimpanan dan transfer energi dalam proses metabolisme tanaman. Unsur P turut berperan dalam peningkatan komponen hasil tanaman kailan yaitu berupa daun.

Perlakuan frekuensi pemupukan nitrogen tidak berpengaruh nyata terhadap rerata luas daun tanaman kailan. Hal ini diduga karena pupuk urea yang digunakan tidak terserap secara maksmimal pada tanaman. Putra et al. (2015) menyatakan bahwa pupuk urea bersifat mobil sehingga mengalami pencucian hara dan mudah oleh aliran air terutama saat terjadi hujan. Daun merupakan organ penting tanaman sayuran, daun daun digunakan untuk proses fotosintesis. Hasil fotosintesis berupa fotosintat digunakan untuk pertumbuhan tanaman. Indriyani et al. (2018) menyatakan bahwa tanaman yang mempunyai luas daun lebih besar, lebih banyak menyerap sinar matahari yang bermanfaat dalam proses fotosintesis

\section{Bobot Basah Tajuk}

Hasil analisis ragam menunjukkan bahwa dosis pupuk kandang kambing dan frekuensi pemupukan nitrogen masing-masing berpengaruh nyata terhadap bobot basah tajuk. Tidak terdapat pengaruh interaksi antara dosis pupuk kandang kambing dan frekuensi pemupukan nitrogen terhadap bobot basah tajuk. Rerata bobot basah tajuk tanaman kailan (Brassica oleracea var. Alboglabra) pada berbagai dosis pupuk kandang kambing dan frekuensi pemupukan nitrogen dapat dilihat pada Tabel 4.

Berdasarkan Tabel 4. diketahui bahwa rerata bobot basah tajuk tanaman kailan dipengaruhi oleh dosis pupuk kandang kambing dan frekuensi pemupukan nitrogen. Dosis pupuk kandang kambing 30 ton/ha meningkatkan bobot basah tajuk secara signifikan sebesar 202,84\% dibandingkan perlakuan tanpa pupuk kandang kambing, diikuti dengan dosis pupuk 20 ton/ha yang meningkat sebesar 78,24\%. Perlakuan dosis pupuk kandang kambing 10 ton/ha belum mampu meningkatkan bobot basah tajuk tanaman kailan secara signifikan. Hal ini diduga semakin besar dosis pupuk kandang yang diaplikasikan ke tanaman, unsur hara 
Tabel 4. Rerata Bobot Basah Tajuk Kailan (Brassica oleracea var. Alboglabra) pada Dosis Pupuk Kandang Kambing dan Frekuensi Pemupukan Nitrogen.

\begin{tabular}{ccccc}
\hline \hline \multirow{2}{*}{$\begin{array}{c}\text { Pupuk kandang } \\
\text { kambing (ton/ha) }\end{array}$} & \multicolumn{3}{c}{ Frekuensi pemupukan nitrogen (kali) } & \multirow{2}{*}{ Rerata } \\
\cline { 2 - 3 } & Satu (2 MST) & Dua (2, 3, MST) & Tiga $(2,3,4$ MST) & \\
\hline 0 & 33,44 & $----(g / t a n a m a n)-----$ & $39,48^{\mathrm{c}}$ \\
10 & 32,27 & 44,56 & 40,44 & $48,50^{\mathrm{c}}$ \\
20 & 56,33 & 69,05 & 44,17 & $70,37^{\mathrm{b}}$ \\
30 & 107,33 & 75,94 & 78,83 & $119,56^{\mathrm{a}}$ \\
Rerata & $57,34^{\mathrm{b}}$ & 124,16 & 127,17 & \\
\hline
\end{tabular}

Keterangan: Superskrip yang berbeda pada kolom atau baris yang sama menunjukkan perbedaan nyata pada uji DMRT taraf $5 \%$.

yang diserap oleh tanaman semakin optimal. Meningkatnya ketersediaan hara maka pertumbuhan dan produktivitas tanaman juga semakin optimal. Hal ini didukung oleh pernyataan Rastiyanto et al. (2013) yang menyatakan bahwa pemberian pupuk organik kotoran kambing dapat meningkatkan ketersediaan nitrogen, posfor dan unsur lainnya yang dibutuhkan tanaman. Agar mencapai bobot basah yang optimal, tanaman membutuhkan unsur hara untuk meningkatkan pertumbuhan vegetatif. Adriani dan Syahfari (2017) menyatakan bahwa semakin tinggi tanaman dan semakin banyak daun yang terbentuk maka menghasilkan bobot basah tanaman yang tinggi pula.

Perlakuan frekuensi pemupukan nitrogen dua dan tiga kali meningkatkan bobot basah tajuk secara signifikan dibandingkan dengan pemupukan nitrogen sekaligus. Pemupukan nitrogen dengan frekuensi sebanyak dua kali meningkatkan bobot basah tajuk menjadi 78,43 $\mathrm{g} /$ tanaman, dan frekuensi pemupukan nitrogen sebanyak tiga kali meningkatkan bobot basah tajuk menjadi 72,65 g/tanaman. Hal ini diduga frekuensi pemupukan nitrogen sebanyak dua dan tiga kali merupakan dosis dan waktu pemupukan yang tepat untuk menghasilkan bobot basah yang optimal. Sarif et al. (2015) yang menyatakan bahwa unsur hara $\mathrm{N}$ yang dikandung dalam pupuk urea besar kegunaannya bagi tanaman dalam proses fotosintesis yang selanjutnya menghasilkan output berupa fotosintat. Fotosintat yang banyak teralokasi secara sempurna ke seluruh bagian tanaman berpengaruh pada bobot basah tanaman.

\section{Kadar ANR (Aktivitas Nitrat Reduktase)}

Hasil analisis ragam menunjukkan bahwa dosis pupuk kandang kambing dan frekuensi pemupukan nitrogen masing-masing tidak berpengaruh nyata terhadap kadar ANR. Tidak terdapat pengaruh interaksi antara dosis pupuk kandang kambing dan frekuensi pemupukan nitrogen terhadap kadar ANR. Rerata kadar ANR tanaman kailan (Brassica oleracea var. Alboglabra) pada berbagai dosis pupuk kandang kambing dan frekuensi pemupukan nitrogen dapat dilihat pada Tabel 5 .

Berdasarkan Tabel 5 diketahui bahwa rerata kadar ANR tanaman kailan tidak dipengaruhi oleh dosis pupuk kandang kambing maupun frekuensi pemupukan nitrogen. Kadar ANR tanaman kailan yang diberi pupuk kandang kambing pada dosis yang diuji menunjukan hasil yang setara. Terdapat kecenderungan bahwa kadar ANR semakin tinggi pada dosis pupuk kandang kambing yang lebih tinggi. Purbajanti et al. (2010) menyatakan bahwa pemberian pupuk kandang pada dosis tertentu dapat menghasilkan ANR lebih tinggi dibandingkan tanpa pupuk kandang. Peristiwa ini dikarenakan pupuk yang mengandung unsur $\mathrm{N}$, baik dalam bentuk nitrat atau amonium dapat menambah jumlah $\mathrm{N}$ dalam tanah sehingga dapat dimanfaatkan tanaman untuk proses metabolisme terutama pada daun. Selain itu pupuk kandang dapat memperbaiki $\mathrm{pH}$ dalam tanah sehingga tanah 
Tabel 5. Rerata Kadar ANR Kailan (Brassica oleracea var. Alboglabra) pada Dosis Pupuk Kandang Kambing dan Frekuensi Pemupukan Nitrogen.

\begin{tabular}{ccccc}
\hline \hline \multirow{2}{*}{$\begin{array}{c}\text { Pupuk kandang } \\
\text { kambing (ton/ha) }\end{array}$} & \multicolumn{3}{c}{ Frekuensi pemupukan nitrogen (kali) } & \multirow{2}{*}{ Rerata } \\
\cline { 2 - 3 } & Satu (2 MST) & Dua $(2,3, \mathrm{MST})$ & Tiga $(2,3,4 \mathrm{MST})$ & \\
\hline 0 & 1,33 & $-----\left(\mu \mathrm{mol.g}^{-1}\right.$.jam $\left.^{-1}\right)$----- \\
10 & 1,82 & 1,45 & 1,96 & 1,58 \\
20 & 1,94 & 2,28 & 2,30 & 2,13 \\
30 & 2,42 & 2,59 & 2,72 & 2,42 \\
Rerata & 1,88 & 2,64 & 2,69 & 2,58 \\
\hline
\end{tabular}

lebih baik dalam menyediakan unsur hara termasuk nitrogen yang berfungsi dalam proses aktivitas nitrat reduktase. Menurut Primavani dan Zulaika (2014) penambahan bahwa pupuk organik dapat meningkatkan nitrat yang tersedia dan aktivitas nitrat reduktase (ANR) menjadi lebih maksiamal. Sebagian besar nitrat yang terserap dialokasikan ke daun, sehingga mengakibatkan meningkatnya ANR di daun.

Frekuensi pemupukan nitrogen sebanyak satu, dua, dan tiga kali tidak mempengaruhi peningkatan kadar ANR tanaman kailan. Hal ini dikarenakan dosis urea yang diaplikasikan sama, hanya frekuensinya yang berbeda. Terdapat kemungkinan bahwa dosis pupuk urea yang berbeda lebih mempengaruhi besarnya kadar ANR kailan dibandingkan dosis yang sama dengan frekuensi berbeda. Hal ini sesuai dengan pendapat Coronel et al. (2009) semakin tinggi dosis $\mathrm{N}$ yang diberikan pada tanaman, semakin tinggi pula kadar ANR-nya. Qorimah (2019) menyatakan bahwa penambahan pupuk $\mathrm{N}$ dapat dilakukan untuk mengoptimalkan aktivitas enzim nitrat reduktase. Pupuk N juga dapat membentuk zat pengatur tumbuh, seperti sitokinin dan giberelin yang dapat untuk meningkatkan kadar ANR.

\section{SIMPULAN}

Berasarkan hasil penelitian dapat disimpulkan bahwa dosis pupuk kandang kambing 30 ton/ha memberikan rerata bobot basah tajuk kailan tertinggi secara signifikan yaitu sebesar 119,56 g/tanaman. Frekuensi pemupukan nitrogen terbaik yaitu pemupukan nitrogen sebanyak dua kali pada bobot basah tajuk sebesar 78,43 g/tanaman. Frekuensi pemupukan nitrogen sebanyak dua kali tidak berbeda nyata dengan frekuensi pemupukan nitrogen tiga kali pada parameter tinggi tanaman dan jumlah daun. Frekuensi pemupukan nitrogen dua dan tiga kali memberikan respon yang baik secara signifikan dibandingkan dengan pemberian pupuk nitrogen sekaligus. Tidak terdapat interaksi antara dosis pupuk kandang kambing dan frekuensi pemupukan nitrogen yang berbeda pada seluruh parameter yang diamati.

\section{DAFTAR PUSTAKA}

Adriani, dan H. Syahfari. 2017. Pengaruh waktu pemberian dan dosis pupuk kandang sapi terhadap pertumbuhan dan hasil tanaman sawi (Brassica juncea L.). Jurnal Agrifor, 16 (2) : 151 - 162.

Azizah, N., G. Haryono, dan Tujiyanta. 2016. Respon macam pupuk organik dan macam mulsa terhadap hasil tanaman sawi caisim (Brassica juncea, 1.) var. Tosakan. Jurnal Ilmu Pertanian Tropika dan Subtropika, 1 (1) : 44 - 51.

Coronel, G., M. Chang, and A. R. Delfin. 2009. Nitrate reductase activity and chlorophyll content in lettuce plants grown hydroponically and organically. Journal of Acta Hort, 843 (843) : 137 - 144.

Erawan. D, Y. W. Ode dan Bahrun. 2013. Pertumbuhan dan hasil tanaman sawi (Brassica juncea L.) pada berbagai dosis 
pupuk urea. Jurnal Agroteknos, 3 (1) : 19 -25 .

Hariodamar, H., M. Santoso, dan M. Nawawi. 2018. Pengaruh pemberian pupuk nitrogen terhadap pertumbuhan dan hasil dua varietas tanaman sawi (Brassica juncea L.). Jurnal Produksi Tanaman, 6 (9) : $2133-2141$.

Haryadi, D., H. Yetti, dan S. Yoseva. 2015. Pengaruh pemberian beberapa jenis pupuk terhadap pertumbuhan dan produksi tanaman kailan (Brassica alboglabra L.). Jurnal Online Mahasiswa Faperta, 2 (2) : 1 - 10.

Indriyani, N., T. Wardiyati, dan M. Nawawi. 2018. Pengaruh macam pupuk kandang terhadap pertumbuhan dan hasil tanaman Brassica rapa L. dan Brasscia juncea L. Jurnal Produksi Tanaman, 6 (5) : 734 741.

Lestari, S. A. D. dan H. Kuntyastuti. 2016. Pengaruh pupuk kandang dan pupuk anorganik terhadap berbagai varietas kacang hijau di tanah masam. Buletin Palawija, 14 (2) : 55 - 62.

Pramitasari, H. E., T. Wardiyati, dan M. Nawawi. 2016. Pengaruh dosis pupuk nitrogen dan tingkat kepadatan tanaman terhadap pertumbuhan dan hasil tanaman kailan (Brassica oleraceae L.). Jurnal Produksi Tanaman, 4 (1) : 45 - 56.

Primavani, F. dan E. Zulaika. 2014. Enzim nitrat reduktase sebagai indikator keberhasilan fitoremediasi pada lumpur sidoarjo. Jurnal Purifikasi, 14 (2) : 118 124.

Purbajanti, E. D., R. D. Soetrisno, E. Hanudin, dan S. P. S. Budhi. 2010. Penampilan fisiologi dan hasil rumput benggala (Panicum maximum Jacq.) pada tanah salin akibat pemberian pupuk kandang, gypsum dan sumber nitrogen. Jurnal Ilmu-ilmu Pertanian Indonesia, 12 (1) : $61-67$.

Putra, A. D., M. M. B. Damanik, dan H. Hanum. 2015. Aplikasi pupuk urea dan pupuk kandang kambing untuk meningkatkan N-total pada tanah inceptisol kwala bekala dan kaitannya terhadap pertumbuhan tanaman jagung (Zea mays L.). Jurnal Online Agroekoteknologi, 3 (1) : 128 - 135.

Qorimah, U. K. N. 2019. Aktivitas nitrat reduktase Capsicum annum L. secara in vivo dengan spektrofotometri. Journal of EPiC, 1 (2) : 95 - 100.

Rahayu, T. B., B. H. Simanjuntak, dan Suprihati. 2014. Pemberian kotoran kambing terhadap pertumbuhan dan hasil wortel (Daucus carota) dan bawang daun (Allium fistulosum L.) dengan budidaya tumpangsari. Jurnal AGRIC, 26 (1) : 52 60

Rajak, O., J. R. Patty, dan J. I. Nendissa. 2016. Pengaruh dosis dan interval waktu pemberian pupuk organik cair BMW terhadap pertumbuhan dan produksi tanaman sawi (Brassica juncea L.). Jurnal Budidaya Pertanian, 12 (2) : 66 73.

Rastiyanto, E., Sutirman, dan A. Pullaila. 2013. Pengaruh pemberian pupuk organik kotoran kambing terhadap pertumbuhan dan hasil tanaman kailan (Brassica oleraceae. L). Buletin IKATAN, 3 (2) : 36 -40 .

Roidah, I. D. 2013. Manfaat penggunaan pupuk organik untuk kesuburan tanah. Jurnal Universitas Tulungagung BONOROWO, 1 (1) : 30 - 42.

Sarif, P., A. Hadid, dan I. Wahyudi. 2015. Pertumbuhan dan hasil tanaman sawi (Brassica juncea L.) akibat pemberian berbagai dosis pupuk urea. Jurnal Agrotekbis, 3 (5) : 585 - 591.

Sinaga, P., Meriani, dan Y. Hasanah. 2014. Respons pertumbuhan dan produksi kailan (Brassica oleraceae L.) pada pemberian berbagai dosis pupuk organik cair paitan (Tithonia diversifolia (Hemsl.) Gray). Jurnal Online Agroekoteknologi, 2 (4) : $1584-1588$.

Suminarti, N. E. 2010. Pengaruh pemupukan N dan $\mathrm{K}$ pada pertumbuhan dan hasil tanaman talas yang ditanam di lahan kering. Jurnal Akta Agrosia, 13 (1) : 1 7. 
Suparhun, S., M. Anshar, dan Y. Tambing. 2015. Pengaruh pupuk oganik dan POC dari kotoran kambing terhadap pertumbuhan tanaman sawi (Brassica juncea L.). Jurnal Agrotekbis, 3 (5) : 602 -611 .

Trisnawati, U., S. Fajriani, dan Y. B. S. Heddy. 2018. Pengaruh pemberian biovaktor terhadap pertumbuhan dan hasil tanaman sawi (Brassica juncea L.). Jurnal Produksi Tanaman, 6 (10) : 2423 - 2430. Wahyudi. 2010. Petunjuk Praktis Bertanam Sayuran. Agromedia Pustaka, Jakarta.

Yuliarta, B., M. Santoso dan Y. B. S. Heddy. 2014. Pengaruh biourine sapi dan berbagai dosis pupuk NPK terhadap pertumbuhan dan hasil selada crop (Lactuca sativa L.). Jurnal Produksi Tanaman, 1 (6) : $522-5$. 